\title{
Developing Cooperative Law Culture at Bmt (Baitul Maal Wa Tamwil) to Remove The Rente System in The Traditional Market
}

\author{
N Triana ${ }^{1}$, Naqiyah ${ }^{1}$ \\ ${ }^{1}$ IAIN Purwokerto \\ Email: triananita@ymail.com, Naqiyah.mukhtar@gmail.com
}

\begin{abstract}
This study aims to uncover and build Baitul Maal wa Tamwil (BMT) with the cooperative legal culture to eliminate rent systems in traditional markets. The research questions are: how is the existing condition of BMT legal culture and how to build new construction of cooperative legal culture on BMT. This research uses qualitative type of research, a traditional non-doctrinal legal research, with a socio legal approach. The results showed that the business of borrowing money with a very high interest or the practice of loan sharks until now is still rampant in a number of traditional markets, the practice of loan sharks in the form of Plecit Bank or UcekUcek Bank remains in demand by the public. The existence of Baitul Maal wa Tamwil (BMT) apparently has not been able to play a optimal role in traditional markets. BMT is under the legal umbrella of cooperatives in practice apply to the Bank. such as borrowing money with a high margin, there is still a guarantee, a long process and consider the customer as a banking customer, not as a member, so there is no cultural closeness. For this reason, it is necessary to establish a legal culture in BMT that has a cultural spirit and cooperative spirit, namely mutual cooperation and togetherness, from members to members. all the benefits of the cooperative achieved by the group, can always be felt directly by all members.
\end{abstract}




\section{Introduction}

The business of lending money at very high interest rates or the practice of loan sharks is still prevalent in a number of traditional markets. Many traders are in debt because it is difficult to repay loans to loan sharks. The existence of loan sharks in traditional markets is inseparable from the paradigm that developed among traders. The process of applying for loans in banks is complicated. For example, the process of applying for a loan at a bank must be accompanied by appropriate collateral.( https://ekonomi.kompas.com/read/2017/05/06/143000626/mengapa.praktik.rentenir.masih. membelenggu.pedagang.pasar).

Difficulties in accessing market traders and / or doing business in the market to sources of capital are often the reason why many people are trapped in loan sharks who provide various facilities, such as being able to borrow without interest, visiting market communities with a friendly cultural approach, but behind that it brings difficulties borrowers money because of the high interest costs that must be returned.

The research result from Tini Hayatur Rohmah $\{13\}$ entitled Plecit Bank Practices in Traditional Markets in Patikraja Subdistrict, Banyumas, showed the size of the practice of loan sharks in the form of Plecit Bank or Ucek-Ucek Bank in traditional markets. Plecit Bank is still in demand by the community, because it is easy for the loan process, and the market community is close enough to Plecit Bank officers who come to greet them every day. The existence of financial institutions around the market such as BMT Baitul Maal wa Tamwil has not been able to play an optimal role in this market, eventhough the existence of Shari'ah Financial Institutions, such as BMT is needed to be able to provide solutions to problems faced in eliminating the entrapment of market communities with loan sharks, while reducing level of poverty among rural communities.

Baitul Maal wa Tamwil (BMT) or also called "Sharia Cooperative", is a sharia financial institution that functions to collect and channel funds to its members and usually operates on a micro scale. BMT consists of two terms, namely "baitul maal" and "baitul tamwil". Baitul maal is a term for organizations which play an important role in collecting and channeling non-profit funds, such as zakat, infaq and shadaqoh. Baitul tamwil is a term for organizations that collect and channel commercial funds. thus BMT has a dual role, namely social functions and commercial functions $\{16\}$. Based on this definition, BMT can be maximized as a financial institution that can eliminate rent and loan sharks.

Based on this background, it is very important to conduct research to build the BMT Baitul Maal wa Tamwil as a strategic financial institution to eradicate rent systems in traditional markets.

\section{Materials and Methods}


This research is a non-doctrinal legal research, with a socio-legal approach $\{8\}$ see also $\{15\}$. Through a sociolegal approach, the legal object is positioned in a broad social context, by not placing it as material isolated from culture (systems of thought, knowledge systems) and power relations between law makers, law enforcement, parties and the wider community. Understanding that law is a set of norms that are separated from social unity will only deny the relevance of law as the norm from the social basis of the birth of the law and the place where the law works. Through this approach, the assessment is carried out by describing the substance of legal norms and social reality, and the interrelationships between the two objects of study.

\section{Results and Discussion}

\section{Loan Sharks on Traditional Markets}

The economic process of the community is largely sustained in a buying and selling process and this occurs in traditional markets. The traditional market is a market that is managed simply with a traditional physical form that implements a direct transaction bargaining system where the main function is to serve the needs of the community both in villages, sub-districts and others $\{11\}$. Prices in traditional markets have uncertain properties, therefore bargaining can be done. Buyers in traditional markets (usually mothers) have behaviors that are happy to transact with communication / dialogue in terms of pricing, looking for the quality of goods, ordering desired items, and the development of other prices.

Some traditional market consumers are middle to lower class people who have very price-sensitive characteristics. When the low price factor which was previously the superiority of the traditional market was able to be torn down by the modern market, there was relatively no reason for consumers from the lower middle class not to go shopping in the modern market and leave the traditional market.

Goods sold in traditional markets are generally local goods and are viewed in terms of quality and quantity, goods sold in traditional markets through less stringent sorting. The distribution chain in traditional markets consists of producers, distributors, sub-distributors, retailers, consumers $\{1\}$. Constraints faced in traditional markets include payment systems to distributors or sub distributors in cash, sellers cannot carry out promotions or provide commodity discounts. They can only reduce the price of goods that are less attractive to consumers. In addition, it can experience difficulties in fulfilling the continuity of goods, weak in mastering technology and management, thus weakening competitiveness (12).

Traditional market traders face almost the same problem, namely the inability to develop because of lack of support both materially and skillfully. Small traders are constrained in the velocity of money and eventually owed. The most familiar financial institution in the traditional market is a daily bank 
with a loan system with a very high interest rate. With this system, many small traders are trapped by loan sharks.

Loan sharks are people who lend money to customers in order to earn profits through interest withdrawals. People who make a living by lending money; handyman usury; money release; loan sharks. Renten activities are a form of activity that provides loans to people in need in the form of interest payments determined by the renters $\{2\}$. The target of loan sharks is small traders in the markets and poor people in the villages. These loan sharks make use of the innocence of these poor people to reap huge profits. They offer convenience in obtaining any amount of money without any guarantee and anytime-anywhere.

This convenience is the reason for the majority of residents to accept money lenders and borrow money from them, even though they have already known the amount of interest they have to pay. The amount of interest is charged, resulting in more debt. The original debt was only Rp. 1,000,000.00 in one month to Rp. 1,200,000.00. This is known as the "rolasan" system. If it is due, it can not pay, then the debt and interest will be repaid, so from Rp. 1,200,000.00 to Rp. 1,400,000.00. So when we reached $\mathrm{Rp} 10,000,000.00$, then within one month he has to return $\mathrm{Rp} 12,000,000.00$.

The loan system provided by loan sharks is the Daily Bank / Package Loans, Payday Payments Weekly / Monthly Interest, and Rent Pawn. Based on the results of the study $\{10\}$ the practice of borrowing money from the community does not have to borrow money from loan sharks, meaning the debtor or the borrower himself comes to borrow from the loan sharks and agrees to the interest set by the loan sharks. This illustrates that between the two agreements have occurred and have been equally willing about the interest set, the flowering of money (rent) that is practiced has multiplied because the creditor must pay his debt every day along with interest set, during the specified time and if it is too late to pay the next day you have to pay two days and so on, this causes the debtor to object and it is difficult to pay. Moreover, if the debtor is not good at using or borrowing it is not used for productive needs, it will have a negative impact and result in the family's economy being poor because they have to share income for family needs and to pay installments to loan sharks.

\section{The Challenge of BMT Against Moneylenders}

BMT is a micro-economic actor and can be stated as a new economic actor in the national economy, but seeing its vision and mission, BMT has a very strategic role, by contributing to the movement of the small economy that is very real, namely by participating in empowerment poor people and MSMEs.

The characteristics of BMT are as follows: 
- $\quad$ Business-oriented, looking for mutual profits, increasing economic utilization the most for members and the community and environment.

- Not a social institution, but it is useful to make effective use of social funds for the welfare of many people and can organize educational activities can empower its members in order to support the economy.

- Grow from below based on the participation of the surrounding community. Owned by small communities from the BMT environment itself, not belonging to individuals or people from outside the community. On this basis BMT cannot be incorporated into the company.

- $\quad$ BMT is committed to meeting allcomponent of society under the layers through forums for recitation, da'wah, education, and socio-economic activities that have implications to productive activities in the economic field. BMT management and operations are carried out according to a professional approach with Islam methods.

The operating principle is based on the principle of profit sharing, buying and selling (ijarah), and deposit (wadiah). Therefore, even though it is similar to an Islamic bank, it can even be said to be the forerunner of an Islamic bank, BMT has its own market share, namely small communities that are not affordable banking services and small business actors who experience "psychological" obstacles when dealing with banks. Baitul Maal Wat Tamwil has several functions, including the following:

- Grouper and channeling funds, by way of saving money in BMT, the money can be enhanced utility, which raised the surplus units (those who have excess funds) and unit deficit (the party that lack of funds).

- The creator and provider of liquidity, can create legal payment instruments capable of providing the ability to fulfill the obligations of an institution / individual.

- Source of income, BMT can create jobs and provide income to its employees.

- Information sharing, giving information to the public about the risks of the advantages and opportunities that exist in the institution.

- As an Islamic microfinance institution that can provide funding for small, micro, medium and also excess cooperatives, it does not require burdensome guarantees for these MSMEs.

In carrying out its business, various contracts that exist in BMT are almost the same as contracts that exist in banks financing Islamic people's banks. The contracts are: in the BMT operational system, the owners of capital invest their money in the BMT not with the motive of getting interest, but in order to get profit-sharing profits. The product of collecting Islamic financial institutions is:

- Wadiah demand deposits, which are savings products that can be withdrawn at any time. Customer funds are deposited in BMT and may be managed. Every time the customer has the right to take it and has the right to get a bonus from the benefits of the use of demand deposits by BMT. The 
amount of the bonus is not set at the beginning but is truly the policy of the BMT. Even so the nominal is sought in such a way as to be always competitive.

- Mudarabah Savings, funds deposited by customers will be managed by BMT, to obtain profits. Profits will be given to customers based on customer agreement. Customers act as shahibul mal and Islamic financial institutions act as mudarib.

- Mudarabah deposits, BMT is free to carry out various businesses that are not contrary to Islam and develop it. BMT is free to manage funds (mudarabah mutaqah). BMT functions as a mudarib and customers are also Shahibul Maal. There are also customer funds that are deposited for certain businesses. Customers limit the use of funds for certain types and places. This type is called mudharabah muqayyadah.

In fact, in the field, some BMT managers still use conventional methods of marketing their products. They collect mudharabah savings and deposits by promising customers a fixed profit every month, whether requested or not, for a certain period of time, for example three months, six months, one year and so on. The amount of this fixed profit is usually aligned with the amount of interest in the conventional bank market at that time.

The reason they put forward was because such a method was considered to be simpler and more effective when most of our society did not yet understand the financial techniques developed by BMT. Another fact also shows that the average BMT manager finds it difficult to offer mudharabah fund collection products to the public. They almost always fail to provide satisfactory answers when prospective customers ask questions about the amount of profit sharing (profit) that will be received each month if the funds are deposited in the BMT.

This has a huge impact, for the next BMT activities, namely for financing activities. This advantage must be given to customers, which is ultimately borne by the Borrowers of funds (Debtors) at the BMT. So that the margin that must be paid by the Borrower (Debtor) to the BMT, is quite large, it can even be greater than the conventional bank interest, even if compared to the loan shark, it is still smaller.

Facts on the ground show, some BMTs apply provisions, recipients of financing facilities are required to return the following principal for the results gradually every month. Even if there is a delay in installment payments, one month, two months and so on, he will be subject to sanctions for payment of fines in the amount of the installment for the month. This is the reason why customers face great difficulties in developing their business. Ironically, although in aqad it is called the portion of profit sharing that can be obtained by both parties if the customer's business is profitable, in the practice the BMT asks for the profit in a fixed amount of rupiah figures. Another fact that has been collected in the 
field is related to the practice of binding guarantees and the provisions regarding the existence of a debt statement for customers for the payment of mudharabah received.

Margin problems or profit sharing like this, are still considered not attractive enough by traders in traditional markets, BMT has not become an alternative choice in financing, so there are still many small traders more interested in daily banks. Because assuming the same between BMT and daily bank (loan sharks) there is still interest in financing.

Another challenge that must be faced by BMTs is the problem of inflexibility (not easy) in carrying out the distribution of funds (financing) BMT. The facts show that BMTs still behave like banks that have a lot of rules so that sometimes they cannot touch small entrepreneurs who are hampered by the rules in banking institutions (such as banks) even though they actually deserve assistance. Problems that generally block small entrepreneurs in asking for assistance in banking institutions (such as banks), namely the issue of credit guarantee eligibility, ownership of business licenses and various other administrative requirements must be met.

Administratively, the following are ways to borrow money from BMT, including:

1. Register for membership, the BMT will only provide loan funds to members and prospective members.

2. Fill in the Loan Form, is the first step as a loan application requirement.

3. Submit a photocopy of your own KTP and a photocopy of your husband and wife (if you are married).

4. Submit photocopies of family cards (KK), electricity bill accounts, salary slips and collateral.

The terms of this BMT when compared to moneylenders are more complicated, especially if this condition has to be done at the BMT office, then the billing is done in the market by uniformed BMT people, then traders are reluctant to do so. because there is a culture of shame found out in debt. They prefer to go to moneylenders, borrow like to neighbors, through chatting for a while and behind the public, nobody knows. This is what causes small traders in traditional markets to depend on moneylenders because, traders are very spoiled with a loan shark system. The reasons are:

1. Moneylenders are people they already know, because loan sharks get along long enough in the market. Greet each other between moneylenders and traders and understand the difficulties of traders

2. Moneylenders come to the merchants kindly (persuade) to provide capital loans.

3. Can be done at any time and under any circumstances even though in urgent circumstances money can be disbursed, even at night.

4. The loan process does not require a long time.

5. The requirement to apply for a loan is not so difficult, without going through complicated forms. different from the bank the conditions must have SIUP, Guarantee and others 
6. To pay installments for moneylenders to the sword, it means that the trader does not have to waste his time paying installments by visiting loan sharks.

7. Without providing collateral in advance (collateral) because of mutual trust

8. Low transaction costs sometimes even without transaction fees

9. Funds obtained are not limited to economic business activities, but the funds are also for urgent activities such as medical expenses, education, and the like.

10. Can be done by all groups, not limited to members only.

11. The borrowing party does not need a KTP, possesses securities or other collateral

For this reason, traders prefer moneylenders as a place to borrow compared to BMT. In fact, moneylenders until now are one of the drivers of ribawi practice in the market. The dependence of traders on the need for money for capital or consumption becomes a profitable business for moneylenders. Even though the system carried out by loan sharks greatly facilitated traders, traders also felt burdened by the existence of loan sharks. The burden that must be borne by the merchant against loan sharks is: 1. Interest that is too large compared to borrowing a bank, cooperative, BMT, etc., 2. The nominal that is forged is relatively small, ie the maximum loan ranges from Rp. 500,000 Rp.1,000,000, - 3. Social sanctions for traders if they cannot afford to pay.

The reason for loan sharks choosing traders as the target of financing is:

1. The possibility of bad credit is small because if the trader is unable to pay social sanctions, the merchant will accept it. For example, if a loan shark collects installments in front of a customer, the trader will immediately pay because he is embarrassed if he does not pay the installments.

2. With a small loan nominal, the trader prefers to pay off the debt rather than close the business, meaning that the trader will not run away from debt because he considers the business more than the debt

3. The velocity of money will be more due to small loans lent with a relatively short period of time.

Based on the facts in the community, it appears that there has been a shift in legal culture from BMT, as a non-bank financial institution with a cooperative legal umbrella, but in the field it still applies as a bank that is capital-based. Legal culture as part of the legal system is important for the operation of law in society. Legal culture which is the human attitude of the legal actors concerned in carrying out the law in society, because as well as any arrangement of legal structures to carry out the stipulated legal rules and as good as any quality of legal substances made without legal culture 
supported by the people involved in the system and the community, law enforcement will not run effectively $\{4\}$

\section{BMT with Hybrid Rules of Cooperatives and Islamic Law}

Lawrence M. Friedman (5) suggests that the effectiveness and success of law enforcement or the running of law depends on three elements of the legal system, namely the legal structure (structure of law), legal substance (substance of the law) and legal culture (legal culture) . The legal structure of law enforcement officials or perpetrators of legal actors in an institution, legal substance including the legislation and legal culture is the living law that is adopted in a society.

Law as a tool to change society or social engineering is nothing but merely the ideas that the law wants to realize (9). To ensure the achievement of legal functions as a better engineering society, not only is the availability of law required in terms of rules or regulations, but also a guarantee for the realization of the rule of law into legal practice, or in other words, guarantee of law enforcement ( good law enforcement). So the operation of the law is not only a mere legislative function, but also an activity of the executor. The implementation of the law will be very effective if the values contained in the rule of law are the manifestation of the intrinsic values that exist in the community concerned which is usually a description of the state ideology.

Philosophically BMT is the embodiment of the Cooperative which is a form of economic activity, mandate of the 1945 constitution. The 1945 Constitution clearly has provided guidance on developing an economic system based on Article 33. At least there are 3 verses in the article that must be operationalized in the economic system. The three verses are: (Paragraph 1) The economy is structured as a joint effort based on the principle of kinship; (Paragraph 2) Production branches that are important to the state and which control the livelihood of many people are controlled by the state; and (Paragraph 3) Earth and water and natural resources contained therein are controlled by the state and are used for the greatest prosperity of the people. The three verses provide 2 important messages, namely (i) family principle is the foundation of economic activity (not economic competition); and (ii) the state has an active role in economic activities because it is given economic control rights in fields of production that are important to the state and which control the livelihoods of many people, as well as natural resources.

The extent of economic democracy based on the constitution contains at least three main things (3). First, the participation of all community members in the national production process. With this way of thinking there should not be members of the community who do not work, all must work and carry out production activities so as to produce economic value. Socially, people who work will have dignity and self-esteem so that they become independent individuals. Second, economic democracy is also 
understood as community participation in contributing to the enjoyment of national production. Even though they have worked, they will not automatically enjoy the production, either directly or indirectly, if the wages given do not take into account the value of "just and civilized humanity". Third, the activities of establishing production and sharing of national production must take place under the leadership and ownership of community members. In other words, all members of the community must also have a national production factor.

Based on this, cooperatives are considered as business buildings that are in accordance with the constitution, because in cooperatives they contain business practices that are in accordance with the soul and constitutional value. First, cooperatives are a collection of ideas / ideas about a movement or economic business organization and contain the principles of economic struggle. This is certainly different from other business entities, such as PT or CV which are individual based and profit oriented. Second, the principles of the economic movement and economic struggle can be seen, among others, from the character of cooperatives which are a collection of people (not capital), equality of votes, and ideals of shared prosperity. Third, the nature of the economy is actually interaction between humans, not capital relations. The implication is that the bargaining position is not determined by the amount of capital, but togetherness relations are framed in mutual welfare. The cooperative clearly shows the accentuation of human relations.

The location of the principle of kinship when associated with cooperative business practices is that the Spirit of Article 33 paragraph 1 actually does not permit the practice of economic competition / competition, but an economic activity that encourages the emergence of "economic cooperation" (cooperation). Economic cooperation in the smallest unit is the joining of people in a business building, just as a cooperative practices. With business practices like this, the dichotomy of relations between workers and owners has never emerged which in economic practice are now often involved in disputes. Next, this collaboration in the meso and macro context operationally brings together the following axis: relationships between businesses (cooperatives) in small / medium and large scale (in production, distribution, etc.), and cooperatives with BUMN / BUMN and the private sector . All relations are framed in matters that have been divided according to Article 33 of the 1945 Constitution.

Finally, the spirit of the cooperative is nothing but togetherness. In short, togetherness is reflected in these three things, namely ownership, determination, and responsibility $\{14\}$. Co-operative ownership is none other than each member is a business owner (cooperative), which is not divided in terms of majority or minority shareholders. Meanwhile, co-operative determination is the manifestation that each decision is taken jointly and each member has the same voting rights. Voting rights are determined based on people, not the number of shares. Finally, co-operative responsibility is 
a consequence of the ownership process and the joint decision. All the benefits and risks of the cooperative business movement are borne together. All of these manifestations of effort are the characteristics of cooperatives and are not found in other business entities.

Philosophical The idea of establishing BMT as a sharia financial institution was born from a sharia economic law system based on three fundamental principles of Islamic teachings, namely Tawhid (Unity of God), Khilafah (Representative) and Is (Justice). The three fundamental principles are applied to sharia financial institutions in the form of the principle of ridha'iyyah (willing to be willing), the principle of benefit, the principle of justice and the principle of mutual benefit. In addition, the principles of muamalah such as family, mutual cooperation, taking advantage and avoiding harm and caring for the weak economic groups became the main basis for the interests of establishing BMT in Indonesia.

Baitul Maal Wat Tamwil (BMT) consists of two terms, namely baitul maal and baitul tamwil. Baitul Maal is more directed at efforts to collect and channel funds that are non-profit, such as: zakat, infaq, and sedeqah. While baitul tamwil as a business of collecting and distributing commercial funds. These efforts become an inseparable part of BMT as an institution supporting economic activities of small communities based on Islam. This institution was established with the intention of facilitating the lower classes of society that is not accessible to the services of Islamic banks or Islamic BPRs.

While juridically the Forms of BMT Legal Entities are diverse, there are BMTs that are legally cooperative, AD / ART refers to Law No. 25 of 1992 concerning Cooperatives. Furthermore, BMTs with legal entities are foundations, AD / ART refers to Law No.28 of 2004 concerning Foundations and finally BMTs that are not incorporated can be categorized as associations or associations.

At present the majority of BMTs that have a cooperative legal umbrella, refer to Law No. 25 of 1992 concerning Cooperatives and PP No. 9 of 1995 concerning the Implementation of Savings and Loan Business Activities by the Cooperative, BMT conducts savings and loan practices, which are implemented in various forms of savings and deposits for storage, and various forms of loan financing products. As Koper BMT has characteristics such as financial institutions that do collect funds and channel them, even if only limited to and for members of cooperatives, prospective members, or other cooperative members. What is meant by prospective members here is to have registered with the cooperative, but have not paid off the deposit of principal savings and other obligations. If the obligations have not been fulfilled within 3 months, it must be removed from the cooperative membership. Savings and Loans Cooperative The regulation is held so as not to clash with the Banking Law and show the Cooperative's existence.

Sociologically, the establishment of BMT in Indonesia is based more on the demands and support of Muslims for the existence of sharia-based financial institutions. As is known, Muslims constitute 
the majority of the population of Indonesia, and there are still many Muslims who still live in the middle to lower classes, but there is no sharia-based financial institution that can reach middle to lower class Muslims, the majority of whom are in villages. The formation of BMT in the centers of life of rural communities is the answer to the needs of these Muslims.

Based on the philosophical, juridical and sociological basis, the ideal BMT is BMT that has the characteristics in accordance with the cooperative. BMT is based on Pancasila and the 1945 Constitution and is based on Islamic sharia principles, faith, integrated cohesion, cooperative kinship, togetherness, independence and professionalism. BMTs must cling to sharia principles. Faith becomes the foundation of the belief to want to grow and develop (6). Integration implies the hope of achieving success in the world and in the hereafter there is integration between the maal side and the social and business tamwil. Kinship and togetherness means that efforts to achieve success are achieved together. Independence means that BMT cannot live only by relying on a helping hand of the government, but must develop from increasing participation of members and the community, for this reason the management pattern must be professional.

In practice, BMT can remove the rent system that is run by daily banks, bank plecit, banks and others by the following way: For the initial stage in managing Baitul Tamwil is to enter the market as a circulation place for financial circulation, goods and services. The main competition for BMTs is moneylenders who have the ease of borrowing and disbursing processes. The process in loan sharks management is very easy, it only takes less than 1 day, sometimes with only a matter of minutes, the money is disbursed. The weakness of the Baitul Tamwil institution is at the speed of disbursement which sometimes takes 1 to 3 days. Therefore, to implement the channeling approach of the Baitul Tamwil strategy, the loan process only lasts one day, the submission of today and tomorrow is disbursed with the guarantee of the original KTP of the borrower.

Ball pick-up service is a service that is one of the main concerns for BMTs so that most of the BMT-BMTs in Indonesia have office locations that are close to markets. In addition to the strategic location, BMT marketing also went directly to the field to receive prospective depositors and customers who made financing. Do not hesitate in learning to loan sharks in terms of relationships and their closeness with traders in the market. Family-friendly approach, greeting kindly in the daily life of the market, will facilitate BMT to attract prospective members.

Keep in mind that BMT is not a Bank. BMT must be born from the community for mutual needs, so BMT members are members of a group of people who feel the same fate, know each other, and feel they have BMT as an institution of unity in the economic and social fields. BMT staff and employees act actively and dynamically, have a positive outlook, and are productive in attracting and managing public funds. BMT offices are opened at certain times and are supported by a number of staff and 
employees to provide services to customers. Others go directly to the field, go to the market, go to homes to find customers, withdraw, and channel funds to customers, deposit funds into BMT cash, monitor, and supervise. This way will be able to slowly remove moneylenders from market life.

Sharia rules must be maintained in BMT financial institutions, as difficult as any conditions faced, BMTs still maintain an economic system that is in accordance with sharia. One of them is the contract system (agreement) that exists in financial institutions that apply sharia patterns to the rules of financing namely mudharabah contract (profit sharing agreement) and murabahah agreement (sale and purchase agreement). contract (agreement) to provide mutual benefits for both parties as partner transactions or cooperation. Agreements (agreements) that have been agreed upon are made in advance so as not to tyrannize both the BMT and debtor customers in the future.

Mudharabah as an aqad that is hard to be implemented by BMT but actually is aqad that can be used and used as a mainstay of BMT in providing capital loans to market traders, to fight (eliminate) loan sharks, This contract is a business partnership agreement between two parties where the first (Shahibul Maal) provides all capital, while the other parties become managers and business profits are divided according to the agreement set forth in the contract. In the mudharabah contract relationship is not between the capital provider, but between the provider of funds (Shahibul Maal) and the entrepreneur (mudharib). From the above understanding it can be seen that BMTs bear all capital while the customer only has expertise capital (but does not have funds). Business profits are divided according to agreement while the overall loss is borne by the capital owner (BMT) as long as it is not due to the manager's negligence. Applications in BMT for mudharabah in terms of financing are: 1 . Working Capital Financing, such as trade working capital and services. Special investment (mudharabah muqayyadah), where special funding sources with special distribution with terms set by Shahibul Mall.

Proportional margin from BMT will be able to attract market people in the product of financing BMT. In determining margin rules, BMTs must be able to compete with loan sharks. As a comparison, the cost of loans to moneylenders is very high. One-time transaction Rp. 1,000,000, then the loan interest is Rp. 200,000, - for 100 days, some even only 50 or 75 days. This is of course very burdensome for the economy of traders and the community. In installments, loan sharks directly deduct payments in front of 100,000 to 200,000 per transaction. Borrowers only get Rp. 900,000 to 800,000 , and must last up to 9 to 10 times taken every week.

BMTs must be able to manage finances so that the proportion is proportional and smaller than moneylenders. The advanced BMT started by way, for loans under 500,000, - Baitul Maal did not take the margin of this as an initial step to help traders to be released from moneylenders. The return system uses a daily system, 2 weeks or once a week this depends on the characteristics of the business 
community. At this stage the Baitul Tamwil provided allowance for financing for 14 days since the financing was disbursed. While the amount of money given is not cut at all where the loan is Rp. $1,000,000$ - immediately given without deductions. The borrower only has the obligation to open a savings account of Rp. 10,000, and also an administration fee of Rp. 10,000, - to purchase matrei and print sale / financing contracts. This method provides great benefits for the market community to be able to develop the business. $80 \%$ of financing customers have savings along with installment payments. Through this facility there is an increase in business scale, increased savings and also infa rate.

BMT can serve all levels and all people who need it, even if for example the community members are non-Muslims. Although BMT is a financial institution that implements sharia rules in its management, BMT still adheres to the principles of tolerance, togetherness of economic prosperity, where transactions are not only specific to serving Muslims. The principle of service to all people is in line with Rahmatan lil 'Alamin's mission which is the main principle in carrying out sharia.

BMT becomes an educational tool to practice bermuamalah in Islamic teachings. BMT together with mosque administrators, mushalla, through pamphlets, leaflets distributed every Friday and also through regular community meetings, conducting direct education to both customers financing the Baitul Tamwil and prospective BMT customers in the market and residents around the market regarding the system for results, various kinds of aqad in BMT and also buying and selling. The latest approach adopted in financing the Baitul Tamwil is the participation of religious leaders and community leaders. This is in the form of an announcement agreement for customers who break promises and cancel payments.

BMT can expand to other business sectors not only in financial services because BMT is a nonbank financial institution, and has two orientations, roles and functions at the same time As mentioned in the definition of BMT in a literal sense, BMT has two orientations, roles and functions at once namely in addition to productive economic profit, BMT also has orientation, role and function in the social (baitul mall). The funds in the BMT come from zakat, infaq and alms funds, in the sense that the funds come from the people and are also channeled to the benefit of the people. From the character and role of BMT that really goes according to the mandate of the constitution and Islamic law, it is optimistic that BMT can eliminate moneylenders, and become heroes of the people's economy. BMT helps people from the downturn and despair of business capital needed by small and medium market traders.

\section{Conclusion}


The business practice of lending money with a very high interest is still rampant in traditional markets. The practice of moneylenders in the form of daily banks, Plecit Bank, Ucek-Ucek Bank, are still in demand by the community because moneylenders have a legal culture that is close to market traders. They also know each other closely and its procedure of financing is very easy. The existence of Baitul Maal wa Tamwil BMT has not been able to play an optimal role in traditional markets. BMTs that are within the cooperative legal umbrella in practice apply as a bank, such as lending money with a high enough margin, there is still a guarantee, long process and it consider customers as banking customers, not as members, so that there is no cultural closeness. For this reason, it is necessary to rebuild the legal culture in BMT based on the Pancasila philosophical values, the juridical basis of cooperative law, and the Islamic legal basis in making the BMT an ideal legal entity that has a cultural spirit and cooperative spirit, namely mutual cooperation and togetherness, from member to member, all cooperative benefits achieved by the group, can always be felt directly by all members. BMT with this mutual cooperation, togetherness and Islamic business will be able to erase the rent system in traditional markets.

\section{Reference}

[1] Aliyah, I., Setioko, B., Pradoto, W. (2016). The Roles of Traditional Markets as the Main Component of Javanese Culture Urban Space (Case Study: The City of Surakarta, Indonesia). IAFOR Journal of Sustainability, Energy \& the Environment, 3(1). https://doi.org/10.22492/ijsee.3.1.06

[2] Arief Moh Zainol Sutrisni, Praktek Rentenir Penghambat Terwujudnya Sistem Hukum Perbankan Syariah di Kabupaten Sumenep. Article - September 2013 with 76 Reads DOI: 10.24929/feb.v3i2.103

[3] Baswir,Revisond.. Koperasi Indonesia Edisi Kedua".Yogyakarta: BPFE.2013

[4] Chambliss J William and Robert B. Seidman, Law, Power and Order, Philipine, AddisonWesley Publishing Company, 1971.

[5] Friedman.M.Lawrence. The Legal System: A Social Science Perspective. New York, Russel Sage Foundation, 1975.

[6] Hudiyanto, Berislam Dengan Koperasi”.Yogyakarta:EKPI IPIEF UMY.2014

[7] Imaniyati Neni Sri . BAITUL MAAL WAT TAMWIL (BMT) Sebagai Pelaku Ekonomi Dalam Perspektif Hukum Ekonomi Nasional. Ringkasan Disertasi Program Doktor Ilmu Hukum Universitas Diponegoro Semarang .2009.

[8] Irianto Sulistyowati , Memperkenalkan Studi Sosiolegal dan Implikasi Metodologisnya, dalam Metode Penelitian Hukum, Konstelasi dan Refleksi. Editor Sulistyowati Irianto dan Sidharta, Jurnal JHMP-FHUI, Yayasan Obor Indonesia, Jakarta, 2009..

[9] Nonet Philippe and Philip Selznick Law and society in transition: toward responsive law. Front Cover. Harper \& Row, Apr 1, 1978 - Law -

[10] Parlina Yeyen, Praktik Pinjaman Rentenir Dan Perkembangan Usaha Pedagang di Pasar Prapatan Panjalin Majalengka . Jurnal Inklusif, Jurnal Pengkajian Penelitian Ekonomi dan Hukum Islam, Vol.2. No.2. 2017

[11] Rohmah Tini Hayatur, Praktik Bank Plecit di Pasar Tradisional Kecamatan Patikraja Kabupaten Banyumas dalam Perspektif Hukum Islam. Thesis IAIN Purwokerto, 2017. 
[12] Sinaga, Pariaman. 2008. Menuju Pasar yang Berorientasi Pada Perilaku Konsumen.

[13] Siswanto, Rudi. Traditional Market Development Study Based Local Wisdom in Indonesia. Sumatra Journal of Disaster, Geography and Geography Education, [S.1.], v. 1, n. 2, p. 211-217, dec. 2017. ISSN 2580-4030. Available at: $<$ http://sjdgge.ppj.unp.ac.id/index.php/Sjdgge/article/view/72>.doi: https://doi.org/10.24036/sjd gge.v1i2.72.

[14] Swasono,Sri-Edi, Kembali ke Pasal 33 UUD 1945 Menolak Neoliberalisme, Jakarta: Yayasan Hatta, 2010.

[15] Wignjosoebroto Soetandyo, Penelitian Hukum dan Hakikatnya sebagai Penelitian Ilmiah, , Ragam-Ragam Penelitian Hukum, Jurnal JHMP-FHUI , 2009

[16] Yaya Rizal, Aji Erlangga Martawireja, dan Ahim Abdurahim. Akuntansi Perbankan Syariah : Teori dan Praktik Kontemporer.Jakarta:Salemba Empat. 2009 